\title{
Organizational Culture is Important to be Implemented by Hospital Management as an Effort to Make Quality of Performance
}

\author{
Mohammad Kamal Musadad Busyairil Bastomi*, Muhardi \\ Hospital Management Master \\ Bandung Islamic University \\ Bandung, Indonesia \\ *tomy_kokams@yahoo.com, muhardi@unisba.ac.id
}

\begin{abstract}
A Hospital as an individual health service agencies that have many services. The multi professions in the hospital which is in each unit that suitable with their field of work, this may causes the background and character of each human resource to be different. The hospital provides comprehensive services to the patients by involving many units that have different tasks. Demands for service quality and existing regulations make the intensity and pressure of work quite high. The activities in the hospital are very dense in every area, both direct services to patients and proponent services even administrative services. The contradiction of the goals and characteristics in each human resource and existing units, on the other hand, must be create a harmonious integration. Union of differences opinion is serves to achieve predetermined goals. This research was conducted qualitatively, the data were obtained by in-depth interviews, observation, and focus on group discussion. Primary data from hospital managers would be analysed qualitatively. The research result states that management must be present at the hospital to manage the hospital complex. The demands for target achievement and harmonious integration are related to the presence of an organizational culture which is created and implemented by hospital management. A positive organizational culture could create harmonious integration which is able to have an optimal quality performance.
\end{abstract}

Keywords—organization, management, hospital, organizational culture

\section{INTRODUCTION}

Hospital is an individual health service institution that serves the field of individual health comprehensively consisting of ER (emergency department), outpatient, inpatient, radiology, laboratory, laundry, pharmacy, medical records, and several other support units. There are many activities in the hospital, both directly serving patients and supporting services. The dynamics in the process of activities in the hospital will appear continuously. The work pressures that exist in the service process can appear at any time.
The hospital as an organization is a forum for achieving the stated goals, namely serving in the health sector, where of course there are activities of existing human resources grouped in certain units. The activities in the hospital are very diverse because they consist of multi professions and multi units that have different work objectives. The emergence of differences in interaction is a natural thing, but all of it must be controlled to create well-directed performance so that management goals, namely efficient and effective, can be realized.

Human resources who will carry out all activities. The key to the success of a hospital lies in harmonious integration and of course played by the existing human resources. Organizational behavior begins with the behavior of every human resource. The complexity and differences that exist in the hospital really interfere with performance so that it must be well controlled. There needs to be a management role in controlling this. Management must make objective and wise concepts to lead human resources to work in harmony so as to increase comfort, motivation, and performance.

Management science recognizes the existence of an organizational culture that is applied in every activity in the organization to create work patterns and systems that produce efficiency and effectiveness. Management and organizational culture are closely related to company management. Management processes within the company that implement a good organizational culture will improve performance. The company has targets and goals that are achieved, this is very closely related to the performance of human resources. Companies always want human resources to perform their work activities optimally [1]. So what is the dynamic in the hospital if management applies the organizational culture well?

\section{RESEARCH METHODS}

This research was conducted qualitatively, the data were obtained by in-depth interviews, observation, and focus on group discussion. This research was conducted at Permata 
Bunda Ciamis General Hospital. Primary data from hospital managers would be analysed qualitatively.

\section{ORGANIZATION AND MANAGEMENT}

Every activity that exists is something that has a purpose. Some activities are carried out individually, some are carried out in groups where both of them have the same goals to be achieved. The goals that have been set and finally carried out in groups are needed or a container as a shelter in carrying out activities. The container is called an organization which consists of groups of people who are active regularly and regularly to achieve predetermined goals [2].

There are many different fields of organization, which depend on the type of goals as outputs and outcomes. Organizations have regular and channeled activities, have a clear concept so that each individual performs activities in accordance with predetermined main tasks and functions. The size of the organization depends on the type of organization itself and the amount of resources available as well as the number of existing units.

A group without a clear concept and pillars is not an organization. The organization must be well managed, in order to achieve a stable activity process and achieve optimal goals. The organization certainly wants to maintain and increase its existence. An organization that achieves optimal results with defined goals and is able to maintain and increase its existence is a successful organization.

Patterns and governance are essential in realizing the efficiency and effectiveness of an activity. An organization which is a group that carries out activities together in accordance with their respective duties and functions, of course, manifested activities that are related to one another. All existing human resources interact with each other to help each other need each other. The use of existing resources requires mutual support. Existing resources are presented in the organization to help human resources carry out activities. Procurement of resources is capital and becomes an organizational asset. Assets need to be maintained and used optimally to facilitate activities to achieve goals.

Efficiency can be defined as optimization and utilization as needed in the operational stage or activities within the organization. Efficiency will make the organization economical in financing, namely the use of costs in accordance with the results achieved. Efficiency is also manifested in the use of resources in existing activities as needed. The process of activities within the organization requires a lot of interaction between human resources as well as between existing units. This interaction must run efficiently, that is, interactions that are simple and easy, so that they do not require interactions that require a long time and require a lot of energy. Every time and energy in the process of activities in the organization is very valuable. Optimization of all resources is a means of realizing efficiency.
Effectiveness is an indicator of the results achieved in accordance with predetermined goals. Every organization has targets in every step of activity and targets globally. The organization must have the resources and then use existing resources to achieve goals in accordance with the targets set. Goals and targets have been determined from the start, so there is a need for management to organize and direct activities within the organization to achieve goals in accordance with the targets.

Management must be present within the organization to function properly. Management is an activity which is a series of management activities that are formed to achieve the goals set. Organizing and managing activities within the organization must be done properly so that efficiency and effectiveness are realized. There is a management function which is also a series of processes, starting from determining plans, creating work structures, delegating tasks and functions as well as moving all resources, and then controlling every activity and evaluating as a whole in order to create new plans that are more efficient and effective.

Organizations need management to manage all activities. Integration between human resources both within one unit and between units requires intense coordination and communication. This process is very important because the organization has one goal, but each individual and each unit has their respective duties that publish their respective goals. The interests and goals of each of these must ultimately remain as one unit to form and realize one goal. Management must have a projected task to regulate all activities including interactions between human resources and between units [3]

Activities within the organization will be directed and controlled by management. The management of both the leadership and the ranks below must be able to read the overall goals of the organization so that they understand these goals. Planning must be drawn up which refers to the objectives that have been set, how, what needs to be done, by whom it is done, when are the right times to run a series and episodes of activities. Planning means that in-depth analysis is needed in order to obtain systems and regulations that will become role models and guidance in every activity. Realizing the goals and targets as well as a series of plans requires both human resources and other resources. Every activity is certainly carried out by human resources by utilizing other resources. The delegation of authority and responsibility to designated human resources must be clear and create a commitment to be able to carry out their duties optimally. Management must be able to move all existing activities, namely ensuring that the tasks in the planned activities are carried out by human resources. Provide enthusiasm and encouragement for human resources to continue their activities and remain in accordance with existing procedures. Monitoring of every activity must be carried out and correcting any discrepancies in the process. Furthermore, management acts as an evaluator of a series of activities that have been carried out, this serves to correct deficiencies by creating innovations and system updates, so 
that organizational performance continues to follow existing conditions and demands.

\section{HOSPITAL}

The hospital as an agency is engaged in individual health services by serving comprehensively and completely by providing service facilities in the form of emergency room, outpatient, inpatient, central surgery, pharmacy, nutrition, laboratory, radiology, and several other supporting services such as laundry, catering, parking, cleaning, admissions, medical records, and several other service units [4]. Existing services in the hospital aim to provide quality health to existing patients. One of the comprehensive services is shown by the number of mutually supportive services, for example, patients go to doctors to treat their illnesses. A series of examinations that are carried out not only in clinical examinations but doctors also need supporting examinations such as the results of blood tests carried out by the laboratory unit, then the doctor diagnoses and provides drug therapy that will be served by the pharmacy unit, the doctor will also easily read the patient's history where historical documentation the patient's health is managed by the medical records unit. It does not stop there that patients who need hospitalization need services like hotels, doctors also need nutritionists to support patient nutrition to help cure their illness. Linen and laundry services are also needed in inpatients, food as nutrition based on the instruction of nutritionists provided by caterers with special standards, a clean and comfortable environment that helps the healing process and prevents secondary hospital infections.

Hospitals with a variety of services with different objectives for each service but must remain one goal in the end, this makes the hospital a complex and unique company. The hospital complex is clearly visible from the number of units that exist in different fields. Each unit is run by human resources with a profession according to the field in the unit. The outpatient unit is of course the activity carried out by the nurse and doctor profession, the nutrition unit is carried out by the nutritionist profession and the catering by the culinary profession, the radiology unit has the radiographer profession, the environmental health unit by the public health profession with its cleaning service, and many others [5].

Hospitals are also unique, namely it is clear that the hospital operates in the field of health services, which consists of doctors, nurses, midwives, analysts, pharmacies and others, but inside the hospital there are also public services, namely incoming patient services with registration and completeness of files. Requirements carried out by the admission division and supported by the administrative group. Hospital services also include hotel services, in which patients who require hospitalization will be placed in rooms with hotel / lodging facilities combined with health services. Patients must be served like in an inn, their room, bedding, cleanliness, until the room payment model is really like lodging services.

The existing multi professions are also multi units with different fields all have one goal, namely to improve the quality of patient health led by the doctor in charge of the patient (DPJP). All professions that provide direct care to patients are called the Caregivers Profession (PPA). Supporting services such as security units by security guards, cleaning by cleaning services supervised by public health professionals, health facilities and support by the IPSRS unit and so on. All units must be connected to each other, coordination and communication must be maintained.

Hospital as an individual health service sector, namely providing services to humans who are not in good health quality. This situation requires the concentration and focus of every available human resource to serve the best possible. Services, one of the indicators of success is a high level of customer satisfaction. Service agencies include hospitals where they provide health services to humans where people have feelings, have hearts, have instincts, want to be respected, can judge and have opinions, and can choose. The hospital serves patients, which means that services are provided to sick people where all conditions are not good, this will also affect the psychological condition of the patient. This situation adds to the weight of the target to be able to provide excellent service quality.

The work pressures associated with multiple professions and multiple units on the other hand must all be integrated. This situation is prone to disagreement between human resources as well as between groups, namely existing units. Each unit has its own duties and functions and of course has its own job targets. Comprehensive service requires each unit to unite to help each other and need each other.

A situation where the patient wants to be served as well as possible amidst bad psychological conditions is vulnerable to demands and disagreements between the patient and human resources or units in the hospital. A situation where the differences in the interests of the units are in accordance with their respective duties and functions, while they are required to unite in one goal with a solid interaction A situation in which various professions with different backgrounds have their assigned duties and responsibilities with existing targets. Demands for excellent service and pressure from patients with their health conditions are very burdensome for human resources in the hospital. All activities in the hospital must clearly be integrated from one unit to another. The complexity of the aforementioned circumstances creates a dynamic in the process of activities in the hospital.

The other side of the existing services in the hospital must continue to run properly in accordance with existing regulations and meet patient satisfaction. Management in the hospital must be able to provide encouragement and motivation to provide a commitment that each human resource and each unit continues to carry out its duties and functions properly in accordance with existing systems and regulations. Management mobilizes all human resources to carry out activities to achieve the stated goals. All elements in the hospital work together in a harmonious and patterned manner according to existing regulatory lines. Hospitals require large operational costs to 
provide excellent service in accordance with patient requests. Hospital management that implements and carries out its functions globally is needed for the sustainability of the hospital and hospital development [6].

\section{Hospital Organizational Culture}

Human resources are the driving force of all activities in the hospital. Hospital is an organization engaged in health services. Hospital as a forum for carrying out activities aimed at individual health services, namely improving the quality of existing patient health. An organization without competent resources will not be able to carry out existing programs so that the achievement of organizational goals is not or less than optimal. It is necessary to increase and develop the quality of human resources in order to increase the performance of an organization [7].

The human resources in the hospital consist of various professions from different backgrounds. Each human resource is recruited by the hospital based on existing needs which aims to carry out activities within the hospital to achieve the goals and targets set. The importance of resources for the continuity of hospital operations, the attention to work ability and the willingness to work must be monitored and quality maintained.

Every activity in the hospital is carried out by human resources where human resources are the only resources that exist in a unique hospital. Human resources as living beings are humans who have different minds, feelings, hearts and attitudes. Humans have behaviors that are manifested in oral and dressing attitudes in their activities. Hospital as an organization which is dense in human resources and full of existing activities, this raises organizational behavior. The emergence of organizational behavior creates colors and nuances of work within the hospital [8].

The complexity and density of activities and demands for quality services coupled with demands for fulfilment of patient rights and safety are routine conditions in the hospital. Dense activities and integration of activities between human resources and between units create social and professional dynamics. Integration between human resources and between units is an absolute must. All differences from each of them will become one goal in the cooperation unit. Management must be able to control this so as not to interfere with performance [3,9].

Organizational culture is known in management which is created by management leaders. Organizational culture is the soul of the organization that forms values, morals, and norms which encourage organizational behavior played by human resources in carrying out all organizational activities in achieving organizational goals. The hospital has management led by directors and ranks under it who can create an organizational culture according to their wishes. A positive organizational culture has also a positive effect on hospital performance. Organizational culture needs to be established and formed, then disseminated, instilled in all human resources, encouragement to implement it either with appeals or also enter into strategic matters, namely organizational culture is included in every existing system and regulation [10].

The culture applied by management in a company, including hospitals, can have a positive influence on human resources. This means that human resources will provide good feedback for the company to work better, be full of enthusiasm, innovate, and focus on the achievement of existing targets and goals. Human resource activity will result in optimal company performance [11,12]. In 2014 Haryanti stated, the performance of a human resource is not influenced by organizational culture, but performance is actually influenced by the competence of existing human resources, this means that it is important to have human resources who have the ability to work [13]. Work motivation is obtained from the influence of existing managerial applications. Human resources must still be motivated in the activity process by including them in the management process, so that it will improve the quality of performance [14]

Based on Miller in Sutrisno [10], there are 8 pillars of organizational culture that have a positive influence on organizational performance. The explanation of the eight pillars is:

\section{A. Goal}

Every organization is created because of the goals to be achieved. Management in an organization must focus on the goals of an organization. The existing vision and mission becomes a reference in running the management wheel. The process is certainly carried out by existing human resources, so management must be able to instill in all human resources an understanding of the goals to be achieved. Furthermore, management must implement its Actuating function (POAC) to move human resources and other resources to focus on existing goals. Organizations where the human resources understand the goals and are projections in every activity will create a successful organization.

\section{B. Consensus}

Various policies in the form of regulations, both guidelines / guidelines, SPO, and others must be issued by the leader in carrying out management, because it is as a direction and guidance in daily activities. Policies must emerge and be implemented properly, loyally and responsibly. Management that has succeeded in creating loyalty and responsibility in implementing existing policies is therefore strong management. Policies must go through a process in order to create policies that are truly wise and ultimately can be executed well. The consensus pillar makes the process of making every decision must be carried out in congregation, namely good deliberation. The deliberation process will produce regulations that are complete, complete, and in accordance with existing laws and values, both internal and external. Deliberation to reach consensus is the key to the birth of quality regulations. 


\section{Unity}

Organization is a social forum, it is clear that there are groups of individuals who interact with each other. The hospital as a large organization has many units and consists of various professions and backgrounds, both education, character, and values. Coordination and communication with a high frequency also occurs, so that there may be clashes both in terms of performance and individually. Management must strive for unity, there should be no division, and the group is sensitive. The running process of management must be disrupted if there are groups that collide with each other. Understanding each other, mutual cooperation, respecting existing conditions are the capital of realized unity.

\section{Achievement}

Achievement is an indicator that human resources have quality and are successful in doing their job. Management must be able to invest in human resources to get achievements in carrying out its activities. If all human resources compete properly to get achievements in accordance with their work and responsibilities, then performance will increase. The successful achievement of organizational goals will be easily realized.

\section{E. Empirical}

The process of achieving goals goes through many activities, it is best if the activities are documented so that lessons can be learned to create even better stages. Experiences of being the best teacher in decision making and creating a better system. Being courageous and willing to understand and understand events that have taken place are considerations and information data that must be used in decision making.

\section{F. Familiarity}

Emotional and spiritual connection is needed in processes and activities. Various kinds of individual traits and backgrounds are very susceptible to disputes due to the lack of mutual understanding and understanding. Management must be able to create any form of stimulation to direct each other between individuals in order to understand each other both in personal form and in the form of job responsibilities.

\section{G. Integrity}

Human resources who carry out all activities within the organization. No matter how good the planning and system is, without operational activities the goals will not be achieved. No matter how good the operation is, without the existence of human resources who have the capacity and quality, the performance will not be optimal. Management must be able to create motivation for human resources so that human resources are obtained that are independent, have high loyalty, are sincere in their work, and have a willingness to innovate.

\section{H. Excellence}

Investing in human resources to achieve maximum results. The resulting product depends on the process of creating the product. There are many resources used in the process of producing an organization's products. Management must be able to instill and create a perspective that existing resources, existing processes, and the results to be achieved must be of high quality. The encouragement and planting of these perceptions will foster a mindset for all activity actors to work as much as possible to achieve results with a quality perspective [10].

Hospital leaders need to create and implement an organizational culture within the hospital in each existing unit. The success of the hospital is determined by indicators of patient satisfaction, satisfaction and comfort so that motivation and performance increase from human resources, the quantity of visits and the number of inpatient bed placements, and the development of the hospital in accordance with existing external developments.

\section{IMPLEMENTATION OF ORGANIZATIONAL CULTURE IN HOSPITALS}

The complexity of the hospital is proven by the number of existing units and the demands for integration between units must run amid the existing dynamics, this requires the hospital to have an optimal management pattern to achieve efficiency and effectiveness. Hospitals have specific goals and are like other organizations in that the hospital is required to provide excellent service because the hospital is a service agency that serves human patients who have feelings, hearts, and feelings that can assess and respond in a complex manner. Hospitals are also dense with existing regulations, all of which aim to make hospitals sustainable, have good quality and quality, and realize patient safety and the safety of human resources. Risk management must always be a paradigm in hospital management.

The hospital description above demands that the hospital's performance be good. Hospital management needs to apply patterns and governance to achieve a successful hospital. Human resources as actors of activities must be given a commitment not an order. Organizational culture is a process that is contained in hospital activities that are managed by management.

The pillars of organizational culture Aim, Achievements and Excellence embedded in each human resource can be an encouragement in carrying out their duties and functions as well as responsibilities. Every human resource that exists will carry out its main duties and functions by using existing resources seriously. These pillars will bring change and a high work rhythm in carrying out activities in accordance with their respective fields. Direct service units for patients such as emergency room, outpatient, pharmacy will always try to provide the best service to provide satisfaction to patients. This unit will always carry out its duties and functions according to their respective fields and sciences. All try to present their best work achievement.

The dynamics of integration between units within the hospital is a problem that must be managed by management in 
order to create good communication and coordination relationships between units. Each unit in the hospital has different objectives, consisting of different professions, from different circles and environments and backgrounds. This difference will bring out the character of each individual and become the projection of the character of each unit. The demand for achievement of the results of the activities of each human resource and each unit will create a high work rhythm. The other side of the hospital is an organization which is a forum for activities that have the same goal, so in the midst of these differences all must be able to unite opinions and unity of understanding and mutual restraint, all of which are implemented in organizational behavior. Organizational behavior is a good action stated in the words, actions, body style and language style that is carried out while doing work in an effort to achieve organizational goals. Organizational behavior can be seen from the behavior and actions of each individual. Hospitals as complex organizations have human resources who must always interact with communication and coordination both within units and individual relationships between units. Good behavior of all or most of the individuals as hospital human resources is the key to a harmonious relationship in carrying out any existing tasks. Harmonization means mutual respect, mutual understanding, mutual understanding, mutual help and cooperation; this is needed by the hospital in running the existing system to create efficiency and effectiveness. Individual behavior will shape organizational behavior which is created by the application of organizational culture.

Organizational culture also has the pillars of Consensus, Familiarity, Empiricism, and Unity. Dense activities and demands for work performance as an effort to create indicators of hospital success will create pressure and selfishness between human resources and units. As previously mentioned, absolute integration is carried out as a comprehensive service effort. The four pillars will unite all differences, bring out a spirit of togetherness, see problems more objectively and unite common goals, namely the achievement of hospital success indicators. A simple example is the integration of an inpatient unit, a nutrition unit, an environmental health unit, a linen unit and a laundry. The treatment of patients with their illnesses needs medical help and is supported by the services of the hospital units. Doctors provide therapy after getting the diagnosis, in an effort to improve the quality of the patient's health, the inpatient unit has the goal of managing patient services while in inpatient care. Coordination with the supply and quality of linens such as bedding, namely blankets, pillows, and bed linen must be communicated with the linen laundry unit. Furthermore, the unit provides linen services that support the patient's healing, clean, fragrant, neat, and sterile. The nutrition unit will also play a role in providing nutritional services that are suitable and optimal for the patient's healing process. Calculation of nutrition, provision of food raw materials, hygienic processing and compliance with existing regulatory rules, as well as presentation and distribution to patients. A clean and healthy environment is an important element in the patient's healing process and risk management for crossinfection in the hospital.

The series of procedures for each of the above units must be carried out in an integrated manner. Communication and coordination must be intense at all times. Differences in the goals, characters, and professions of each unit, if the four pillars of the organizational culture are embedded in every human resource and are contained indirectly in every existing regulation, then all will be able to hold back, will be able to encourage to always close together in discussions, everyone wants look at the existing situation and make a joint analysis to draw conclusions with an agreement that will be carried out together mutually. The high rhythm of work, the density of activities and the amount of performance demands in the hospital, this will be a joint responsibility, because one another understands each other's character, understands each other's interests and targets, and understands that everything is done together. Will be more efficient and effective.

The spirit of achieving the target through mutual cooperation will foster motivation. A good and comfortable working atmosphere grows because of mutual understanding in the midst of busy activities. Human resources that will grow a sense of self-confidence and appreciation so that the willingness to work appears trying to give the best, innovation will also emerge. The performance of human resources will be projected to the performance of the unit and so on the performance of the unit will be projected to the performance of the hospital.

A positive organizational culture requires a leadership role and is welcomed by the implementation of all human resources in organizational activities. Hospital is an organization in the health sector, with the complexity and dynamics that exist both internally and externally, the organization culture is absolutely needed by the hospital. Differences in professions which are required to achieve one goal will create multiple interpretations and projections of different understandings. The different activities and goals of each unit are then required to converge on one goal. The pressure and dynamics of services in the hospital increase the opportunity for differences in understanding and opinion in interacting with each activity. Organizational culture is the key to controlling all the dynamics that exist in every activity in the hospital. Organizational culture is created by the leadership, then socialized, instilled, then included in existing regulations. All human resources, then each unit, will carry out activities in the hospital by following the organizational culture that is exemplified, instilled, and is subject to existing regulations. Organizational culture is a form of habit that is consciously or unconsciously recognized and carried out by every human resource in carrying out duties and activities in the hospital in accordance with certain values, norms, culture, and morals. Organizational culture plays an important role in the density of activities in the hospital. All the dynamics of both service issues, facility problems, regulatory issues and procedures in which many units interact and have objectives of each unit can be controlled by the existence of an organizational culture that has been 
formed. Each individual and unit will fuse their selfishness, think broadly, promote communication, understand each other, and of course look after each other and cooperate in every activity that exists. The elements of organizational culture are clear that it will make all individuals in each unit and each line see a problem wisely and will try to solve it in a wise way, namely objectively seeing the problem and being objective in finding ways to solve it. It is clear that the various fields in the hospital with various characters will see the work, activities, goals, and use of resources for the common interest and the achievement of the same goal. A comfortable atmosphere in activities will relieve the pressure and burden that is. Motivation will grow and then loyalty will emerge so that the quality of the hospital will increase.

\section{CONCLUSION}

Organizational culture must be created by hospital leaders and instilled in all human resources. All existing human resources must be able to carry out the organizational culture in the implementation of activities in the hospital. The complexity of the hospital where the demands for service quality with all available resources as well as the demands for integration between units will create work pressures and differences and problems, this will result in poor communication and coordination that disrupt hospital performance. Organizational culture, namely Purpose, Achievement, Excellence, Consensus, Familiarity, Empirical, Unity, and Integrity can convert all existing dynamics into a resource in fostering morale and interaction between individuals and between units within the hospital. The application of a positive organizational culture makes the work atmosphere comfortable, the workload and pressure turn into motivation, innovation will grow, and performance will increase. Hospitals that apply an organizational culture will become sustainable hospitals and become successful hospitals.

\section{REFERENCES}

[1] B. Udan, Pengaruh Praktek Manajemen Sumber Daya Manusia Terhadap Budaya Organisasi dan Kinerja Perusahaan. Disertasi, Surabaya: Universitas Airlangga, 2002.

[2] A.Y. Hamali, Pemahaman Praktis Administrasi,Organisasi, dan Manajemen-Strategi Mengelola Kelangsungan Hidup Organisasi. Jakarta: Prenada Media Group, 2019.

[3] J.M. Ivancevich, D. Yuwono, dan M.T. Matteson, Perilaku dan Manajemen Organisasi II. Jakarta: Erlangga, 2007.

[4] Undang-Undang Republik Indonesia Nomor 44 Tahun 2009 Tentang Rumah Sakit.

[5] F.E.B. Setyawan dan S. Supriyanto, Manajemen rumah sakit. Sidoarjo: Zifatama Jawara, 2020.

[6] L. Trisnantoro, Memahami penggunaan ilmu ekonomi dalam manajemen rumah sakit. Yogyakarta: UGM press, 2018

[7] Muhardi, Nurdin, dan A. Irfani, Strategi Pengembangan Sumber Daya Insani-Knowledge and Organizational Sustainability. Bandung: CV Ragam dan Pusat Penerbitan Universitas (UNISBA), 2019

[8] M.C. Ulum, Perilaku Organisasi Menuju Orientasi Pemberdayaan. Malang: Universitas Brawijaya Press, 2016.

[9] A. Sobirin, Budaya Organisasi. Yogyakarta: UPP STIM YKPN, 2007.

[10] H.E. Sutrisno, Budaya Organisasi. Jakarta: Prenada Media Group, 2010.

[11] N. Arianty, "Pengaruh budaya organisasi terhadap kinerja pegawai," Jurnal Ilmiah Manajemen dan Bisnis, vol. 14, no. (2), 2015.

[12] H. Semuel dan J. Zulkarnain, "Pengaruh Sistem Manajemen Mutu ISO Terhadap Kinerja Karyawan Melalui Budaya Kualitas Perusahaan," Jurnal Manajemen dan Kewirausahaan, vol. 1, no. (2), p. 162, 2011

[13] S. Haryanti, Pengaruh Gaya Kepemimpinan, Budaya Organisasi, Dan Kompetensi Karyawan Terhadap Kinerja Dengan Komitmen Organisasional Sebagai Variabel Mediasi (Studi Kasus Pada Rumah Sakit Islam Klaten). Surakarta: Doctoral dissertation, UNS (Sebelas Maret University), 2014.

[14] D. Efliani, Pengaruh Motivasi, Budaya Organisasi Dan Komitmen Organisasional Terhadap Kinerja Perawat Di RSUD Dr. Moewardi Surakarta. Surakarta: Doctoral dissertation, Universitas Muhammadiyah Surakarta, 2014 